\title{
Sorption of Cadmium and Lead Ions by Cunninghamella elagans Lender ML2
}

\author{
Manal T. El-Sayed* and FiFi M. Reda \\ Botany Department, Faculty of Science, Zagazig University, \\ Zagazig, Egypt.
}

\begin{abstract}
CUNNINGHAMELLA elegans Lender was isolated from agricultural field treated with sewage industrial effluents. It was selected on the basis of its high frequency for the biosorption potential evaluation of cadmium and lead. Alkali pretreated dead biomass was used for biosorption experiments. The effects of biomass concentration, initial metal concentration, $\mathrm{pH}$, contact time, temperature and agitation rate were studied. The maximum uptake capacities of cadmium and lead ions are $59 \mathrm{mg} / \mathrm{g}$ and $71 \mathrm{mg} / \mathrm{g}$ dry wt biomass at initial concentration of metal ions $300 \mathrm{mg} / \mathrm{L}$ and $200 \mathrm{mg} / \mathrm{L}$ biomass dosage, respectively. The optimum $\mathrm{pH}$ values for cadmium and lead biosorption were 5.0 and 6.0. The best temperature was $25^{\circ} \mathrm{C}$ for cadmium and lead ions. Maximum uptake for cadmium was achieved after $60 \mathrm{~min}$, while for lead after $30 \mathrm{~min}$. The best agitation rate was $120 \mathrm{rpm}$ for both metal ions removal. The technique of scanning electron microscope coupled with energy dispersive X-ray analysis (EDAX) shows that cadmium and lead were exchanged with elements present on the surface of native cells of C. elegans Lender ; thereby suggesting ion exchange as one of the dominant mechanisms of metal biosorption for this fungal strain. Alkali pretreated biomass was tested to remove cadmium and lead ions from three wastewater samples. Cadmium and lead ions were effectively eluted by $15 \mathrm{mM}$ $\mathrm{HNO}_{3}$ and $10 \mathrm{mM}$ EDTA, respectively.
\end{abstract}

Keywords: Biosorption, Cadmium, Lead, Fungi.

Increased industrial and human activities have impact on environment through the disposal of industrial wastewater, sewage and sewage sludge to agricultural land. These wastewaters contain some plant nutrients, organic matter and varying levels of heavy metals (Hayat et al., 2002 and Korboule et al., 2002). The heavy metal pollution is an environmental problem of world wide concern. The big three metals known for their high toxicity and public health risk problems are lead, mercury and cadmium (Volesky, 2007). Cadmium compounds were currently mainly used in rechargeable nickel-cadmium batteries. Cadmium emissions had increased dramatically during the $20^{\text {th }}$ century, one reason being that cadmium containing products were rarely recycled, but often dumped together with household waste. The adverse health effects due to cadmium

*Corresponding author E-mail: Tawfeek.manal1@gmail.com 
exposure may occur at lower exposure levels than previously anticipated, primarily in the form of cancer, but bone fractures, and kidney damage are also possible (Järup, 2003). Lead is extremely toxic and can damage the nervous system, kidney and reproductive system, particularly in children (Sheng et al., 2004 and Gavrilescu, 2004).

Biosorption is a property of certain types of inactive, non-living microbial biomass to bind and concentrate heavy metals from even very dilute aqueous solutions (Ahluwalia \& Goyal, 2007). They added that, biosorption mechanisms are various and in some cases they are still not very well understood. They may be classified according to the dependence on the cells' metabolism; active and passive biosorption and the location where the metal removed from the solution is found (extracellular accumulation/precipitation, cell surface sorption/precipitation and intracellular accumulation).

Many microbial species such as algae, bacteria and fungi are known to have high metal adsorbing capacities (Selatnia et al., 2004a and Chen \& Lian, 2005). Vijayaraghavan \& Yun (2008) reported that the removal of pollutants from waters (industrial and agricultural wastes), especially these that were not easily biodegradable such as metals and dyes, a variety of biomaterials were known to bind these pollutants, including bacteria, fungi and algae. Fungi are better suitable for the removal of metals from wastewater than other microbes because of their great tolerance towards heavy metals and other adverse conditions such as low $\mathrm{pH}$, high chitin content in cell walls, and this polymer of $\mathrm{N}$-acetylglucosamine is an effective metal and radionuclide biosorbent (Tobin et al., 1994). El-Morsy (2004) reported that $C$. echinulata could be employed either in free or immobilized form as a biosorbent of metal ions in wastewater. Schizophyllum commune, Ganoderma lucidum and Pleurotus ostreatus have been also reported as an efficient biosorbents for copper and nickel in relation to chromium and zinc ions from electroplating effluents (Javaid \& Bajwa, 2008).

Living and dead cells of fungi are able to remove ions of heavy metals from aqueous solutions (Kapoor \& Viraraghavan, 1995 and Volesky \& Holan, 1995). There is a number of advantages associated with the use of dead (inactive) biomass such as toxicity of the metals in solution cannot affect the adsorptive function of the biomass, nutrient and other biomass growth requirement do not need to be satisfied in the process, and maintenance of the purity of the culture is not a concern (Bayramoglu et al., 2005). Another advantage of using dead biomass was the sorbed metal ions could be easily desorbed and the biomass could be reused (Selatnia et al., 2004b). The alkali pretreatment was observed to be most effective in increasing the biosorptive capacity of fungal biomass (Göksungur et al., 2005). Also, Amini et al. (2008) studied the outer surface, microporosity and pore size of the non-viable A. niger after treatment by $\mathrm{NaOH}$ using scanning electron microscope. They reported that lead biosorption capacity on dead A. niger biomass was enhanced by that treatment. 
The aim of the present work is the isolation of novel fungal organism for use as a biosorbent and optimization of conditions for use of its biomass to remove cadmium and lead from industrial wastewaters.

\section{Materials and Methods}

Heavy metals analysis of soil

Agricultural field soil of Meet Abou Khalide (Dakahlia Governorate, Egypt) receiving long term application sewage and industrial effluents as irrigant was analyzed for heavy metal content and was used to isolate fungi by spread plate method. For analysis of heavy metals contents, samples were prepared according to the standard method as described by Vanloon \& Lichwa (1973) using atomic absorption spectrophotometer (Model Unicam 969).

\section{Isolation and identification of fungi}

For the isolation of fungi, sabouraud dextrose agar (SDA) medium supplemented with $\mathrm{CdCl}_{2} / \mathrm{Pb}\left(\mathrm{NO}_{3}\right)_{2}$ at $50 \mu \mathrm{g} / \mathrm{ml}$ conc. at $45-50^{\circ} \mathrm{C}$ before pouring the medium into petriplates (Ahmed et al., 2005). $0.1 \mathrm{gm}$ of aseptically collected composite soil was serially diluted in sterile saline up to $10^{-5} .0 .1 \mathrm{ml}$ of various dilutions were spread on SDA plates containing $100 \mu \mathrm{g} / \mathrm{L}$ chloramphenicol to inhibit bacterial growth and incubated at $29^{\circ} \mathrm{C}$ for 7 days. The dominant isolates were transferred into Czapek's agar medium for 7days and identified according to morphological characteristics and characters of spores (Domsch et al., 1980 and Moubasher, 1993).

\section{Biomass preparation}

C. elegans Lender was cultivated in potato dextrose broth prepared from pealed potato tubers and the medium contained $(\mathrm{g} / \mathrm{L})$ potato extract $(230 \mathrm{ml})$, glucose $(20 \mathrm{gm})$ and water $770 \mathrm{ml}$ (Gams et al., 1998). After 7 days of incubation at $28^{\circ} \mathrm{C}$ on rotary shaker at $125 \mathrm{rpm}$, the fungal growth was harvested by filtration. The harvested biomass was washed with generous amount of deionized water to remove residual growth medium and killed by autoclaving $\left(15 \mathrm{lb}, 121^{\circ} \mathrm{C}\right)$, dried in an oven at $80^{\circ} \mathrm{C}$ for $24 \mathrm{hr}$. The dry biomass was powdered to particles by using electric grinder into size ranging from 90 to 500 micrometers (Bai \& Abraham, 2001). Then a chemical treatment is underwent which consists in introducing the dried biomass into a solution of sodium hydroxide of $0.01 \mathrm{~N}$ concentration. The biomass is maintained in suspension by agitation during $30 \mathrm{~min}$ at ambient temperature, repeatedly filtered and washed with distilled water, then dried in the drying oven at $80^{\circ} \mathrm{C}$ until weight remained constant and stored in an air tight container (Krim et al., 2006).

Effect of initial metal concentration and biomass dosage

Biomass concentrations 200, 400 and $600 \mathrm{mg} / \mathrm{L}$ were added to $250 \mathrm{ml}$ Erlenmeyer flasks separately. Aliquots $(50 \mathrm{ml})$ of 100,200 and $300 \mathrm{mg} / \mathrm{L}$ concentration of cadmium chloride and lead nitrate were added to each flask, and the flasks were left $30 \mathrm{~min}$ on a rotary shaker at $120 \mathrm{rpm}$. The samples were filtered. The concentration of unadsorbed cadmium and lead in the supernatants

Egypt. J. Microbiol. 46 (2011) 
were measured by using an atomic adsorption spectrophotometer. Metal uptake (q) was determined from this formula:

$$
\mathrm{q}=\mathrm{V}\left(\mathrm{C}_{\mathrm{i}}-\mathrm{C}_{\mathrm{eq}}\right) / \mathrm{m}
$$

where $\mathrm{q}$ (metal uptake, $\mathrm{mg} / \mathrm{g}$ ) is the amount of metal ions adsorbed on the biosorbent, $\mathrm{V}(\mathrm{mL})$ the volume of metal containing solution in contact with the biosorbent, $\mathrm{C}_{\mathrm{i}}(\mathrm{mg} / \mathrm{L})$ the initial concentration of metal ions in the solution $\mathrm{C}_{\mathrm{eq}}$ $(\mathrm{mg} / \mathrm{L})$ the final concentration of metal ions in the solution and $\mathrm{m}(\mathrm{g})$ is the dry weight of fungal biomass (Gulnaz et al., 2005).

\section{Effect of initial $p H$ on metal removal}

The $\mathrm{pH}$ of solution, ranging from 3 to 7 was studied. No buffers, $1 \mathrm{~N} \mathrm{HC} 1$ or $1 \mathrm{~N} \mathrm{NaOH}$ were used to adjust the initial $\mathrm{pH}$ in case of cadmium and no spontaneous metal precipitation was observed in the prepared solutions after the solution had been in contact with the biosorbent. In the case of lead, $\mathrm{pH}$ was adjusted with $0.1 \mathrm{~N} \mathrm{HNO}_{3}$ or $0.1 \mathrm{~N} \mathrm{NH}_{4} \mathrm{OH}$.

\section{Effect of temperature}

The biosorbent $(200 \mathrm{mg} / \mathrm{L})$ was contacted with heavy metal solutions containing cadmium and lead at an initial concentration of $300 \mathrm{mg} / \mathrm{L}$ in an environmental incubator shaker at $20^{\circ} \mathrm{C}, 25^{\circ} \mathrm{C}, 30^{\circ} \mathrm{C}, 35^{\circ} \mathrm{C}$ and $40^{\circ} \mathrm{C}$.

\section{Effect of agitation rate}

The effect of the turbulence of the sorbent /sorbate system in cadmium and lead adsorption was monitored at 60,120,180 and $200 \mathrm{rpm}$ using a non-agitated system as the control.

\section{Effect of contact time}

The biomass $(200 \mathrm{mg} / \mathrm{L})$ was contacted with cadmium and lead solutions $(300 \mathrm{mg} / \mathrm{L}$ ) for different periods of time. Samples were analyzed every ten minutes and after $24 \mathrm{hr}$ and the adsorption profile was monitored. For all graphical representations, the mean values of the three replicates of the batch experiments were plotted.

Quantification of metal biosorption using Energy Dispersive X-ray (EDAX) microanalysis

Three biomass samples have been prepared for EDAX microanalysis. The pretreated biomass of $C$. elegans Lender was suspended in $100 \mathrm{ml}$ of distilled water amended with $300 \mathrm{mg} / \mathrm{L}$ cadmium or lead, $200 \mathrm{mg} / \mathrm{L}$ of dried biomass under or the previous optimum conditions. The control biomass was suspended in $100 \mathrm{ml}$ of distilled water. Following centrifugation and filtration, each biomass sample was dried in the oven at $60^{\circ} \mathrm{C}$ until constant weight. Then the dried biomass was holded in special capsule for analysis (Ibrahim et al., 2004).

Heavy metals fractions in the dried dead biomass were examined by the Environmental Scanning Electron Microscope (Model Philips xL 30 ESEM) coupled with energy dispersive X-ray analysis (EDAX). These analyses were carried out in the laboratories of Nuclear Material Authority (NMA), Cairo, Egypt.

Egypt. J. Microbiol. 46 (2011) 
Application of cadmium and lead removal capacities by the dried pretreated biomass of C. elegans Lender from different wastewaters

Three wastewater samples were collected from polluted effluents of chemicals factory, dyes factory and battery factory in Tenth of Ramadan City, Industrial region, Sharkia Governorate, Egypt. The initial concentrations of cadmium and lead were determined.

About $100 \mathrm{ml}$ of each wastewater sample were collected and $200 \mathrm{mg} / \mathrm{L}$ of tested dried biomass was added and maintained under obtained optimum conditions. Aliquots of each flask were centrifuged for $15 \mathrm{~min}$ at $5000 \mathrm{rpm}$ and the final concentrations of cadmium and lead were determined.

Elution of metal ions biosorbed by dried pretreated biomass and regeneration

The metal-loaded pretreated biomass after biosorption was conducted with $25 \mathrm{ml}$ of elutants deionized water, $15 \mathrm{mM} \mathrm{HNO} \mathrm{H}_{3}$ and $10 \mathrm{mM}$ EDTA for one hour on a rotary shaker (120rpm) to study the removal of biosorbed metal ions. Metal concentrations were determined after separating the biomass from eluting agents by centrifugation for $15 \mathrm{~min}$ at $5000 \mathrm{rpm}$, and the final concentrations of cadmium and lead were determined. Use of $15 \mathrm{mM} \mathrm{HNO}_{3}$ or $10 \mathrm{mM}$ EDTA solutions as elutants deposits $\mathrm{H}^{+}$ions on the biomass surface. Excessive amounts of $\mathrm{H}^{+}$ions can reduce the metal biosorption capacity of biomass. Therefore, reuse of the fungal biomass in biosorption after elution of biosorbed metal ions will require $\mathrm{H}^{+}$ions to be removed from the biomass. Washing the biomass with deionized water can remove $\mathrm{H}^{+}$ions until the $\mathrm{pH}$ of the wash solution was in the range of 5.0 - 5.4. The biomass regenerated was air dried and its ability to biosorb metal ions was examined (Kapoor et al., 1999).

\section{Results and Discussion}

\section{Occurrence of fungi in polluted soil}

Soil fungi those able to grow in the presence of heavy metals $(50 \mu \mathrm{g} / \mathrm{ml}$ of $\mathrm{CdCl}_{2}$ and $\mathrm{pb}\left(\mathrm{NO}_{3}\right)_{2}$ were isolated and identified. The frequent species were Aspergillus niger Van Tieghem, C. elegans Lender, Cochliobolus lunatus Nelson \& Haasis and Rhizopus arrhizus Went and Prinsen-Geerligs. C. elegans Lender was selected to complete these studies based on its high frequency of occurrence in sampling and it has not been extensively subjected to biosorption studies. It is apparent that certain fungi can exhibited considerable tolerance towards toxic metals and can become dominant microorganisms in some polluted habitats (Gadd, 2007). The heavy metal content of treated and untreated soil is listed in Table 1. The heavy metal contents of treated soil are about two fold or more than the untreated one. The higher amounts of heavy metals in the treated soil are likely due to long-term application of the wastewater containing these heavy metals (Malik \& Jaiswal, 2000). The occurrence of various fungi such as Aspergillus, Penicillium, Alternaria, Geotrichum, Fusarium, Rhizopus, Monilia and Trichoderma in soil polluted with heavy metals (cadmium, nickel, copper, chromium and cobalt) has been also reported by Zafar et al. (2007). 
TABLE 1. Metal concentration in soil sample of agricultural field receiving long-term application of wastewater.

\begin{tabular}{|l|c|c|}
\hline \multirow{2}{*}{ Metal } & \multicolumn{2}{|c|}{ Metal concentration $(\mu \mathrm{g} / \mathbf{g}$ of soil $)$} \\
\cline { 2 - 3 } & Untreated soil & Treated soil \\
\hline $\mathrm{Pb}$ & 20.0 & 45.7 \\
$\mathrm{Ni}$ & 18.4 & 32.8 \\
$\mathrm{Zn}$ & 57.8 & 100 \\
$\mathrm{Cd}$ & 1.0 & 2.2 \\
\hline
\end{tabular}

Because of the important role of cell wall in the metal biosorption by nonviable cells, metal biosorption may be enhanced by heat or chemical sterilization or by grinding. Thus degraded cells would offer a larger available surface area and expose the intracellular components and more surface binding sites due to the destruction of the cell membrane (Errasquin \& Vázquez, 2003). Also, Kapoor \& Viraraghavan (1995) reported that the alkali treatment (usually with sodium hydroxide) of fungal biomass deacetylates chitin present in the cell wall to form chitosan-glucan complexes with higher affinity for metal ions.

Effect of metal ions concentrations and biomass dosage on metal uptake

Cadmium and lead uptake (mg/g biomass) increased at higher concentrations of cadmium and lead ions and lower biomass dose (Fig. 1). From the figure, the maximum uptake of cadmium $(59 \mathrm{mg} / \mathrm{g})$ and lead $(71 \mathrm{mg} / \mathrm{g})$ occurred at a biomass of $200 \mathrm{mg} / \mathrm{L}$ and initial concentration of cadmium and lead ions $300 \mathrm{mg} / \mathrm{L}$. Ions uptake decreased at 400 and $600 \mathrm{mg} / \mathrm{L}$ biomass.

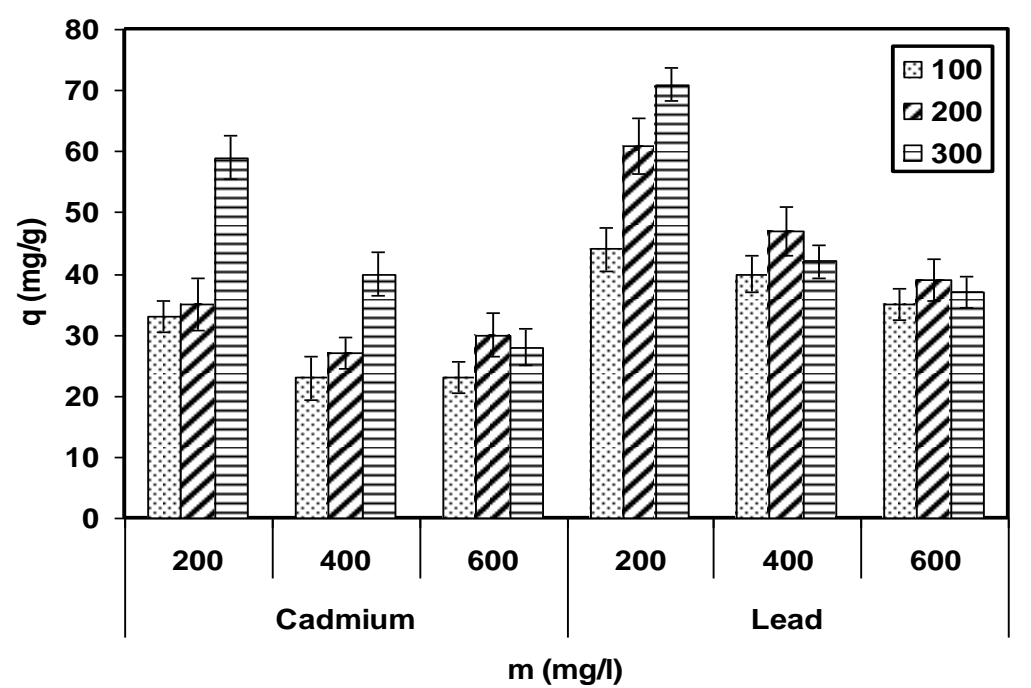

Fig. 1. Effect of initial metal ion concentration $\left(\mathrm{C}_{\mathrm{i}}\right)$ and biomass dosage $(\mathrm{m})$ on $\mathrm{Cd}^{2+}$ and $\mathrm{Pb}^{2+}$ ions sorption capacity of dried pretreated $C$. elegans.

Sorption conditions: $\mathrm{pH}=5.0$ (for $\mathrm{Cd}^{2+}$ ) and $6.0\left(\right.$ for $\left.\mathrm{Pb}^{2+}\right)$; temperature $(\mathrm{T})=25^{\circ} \mathrm{C}$; contact time $=60 \mathrm{~min}\left(\right.$ for $\left.\mathrm{Cd}^{2+}\right)$ and $30 \mathrm{~min}\left(\right.$ for $\left.\mathrm{Pb}^{2+}\right)$ and agitation rate $=120 \mathrm{rpm}$. 
The concentration of both the metal ions and the biosorbent is a significant factor to be considered for effective biosorption. The uptake rate of the metal ion will increase along with increasing the initial concentration if the amount of biomass is kept unchanged. Contrary to that, biosorptive capacity of the metal ions is inversely proportional to the initial concentration of the biomass when the initial concentration is kept constant (Wang \& Chen, 2006). Further, increment in sorbent dose did not cause significant improvement in adsorption. This seems to be due to the binding of almost all ions to the sorbent and the establishment of equilibrium between ions bound to the sorbent and those remaining unadsorbed in the solution (Bai \& Abraham, 2001). Also, Vasudevan et al. (2003) found that the process of cadmium biosorption by inactive and deprotonated cells of Saccharomyces cerevisiae was dependent on the availability of metal ions in aqueous solution or metal ion concentration. Tsekova \& Petrov (2002) reported that at lower biomass concentration the metal/biosorbent ratio was enhanced and thus metal uptake was increased, as long as the biosorbent was not saturated. The decreasing metal uptake at higher biosorbent dosage can be explained by considering a partial cell aggregation that takes place at high biosorbent concentrations causing a decrease in the number of the active sites (Incharoensakdi \& Kitjaharn, 2002).

\section{Effect of initial $\mathrm{pH}$}

The effects of the initial $\mathrm{pH}$ on biosorption of cadmium and lead ions are evaluated in the $\mathrm{pH}$ range of $3-7$ (Fig. 2). Investigation of $\mathrm{pH}$ values above 7 was not possible since metal precipitation appeared and interfered with accumulation. It can be seen that metal uptake increases with increasing $\mathrm{pH}$ from 3 - 5 for cadmium and $\mathrm{pH} 3-6$ for lead. Maximum cadmium and lead ions uptake capacities are 58.02 and $48.70 \mathrm{mg} / \mathrm{g}$ at $\mathrm{pH} 5$ and 6 , respectively.

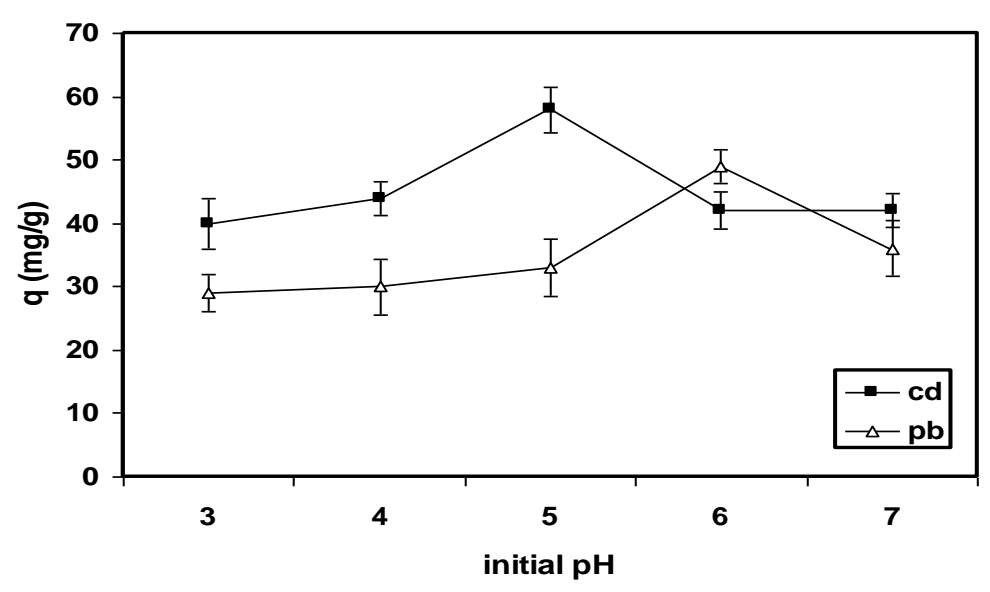

Fig. 2. Effect of initial $\mathrm{pH}$ on $\mathrm{Cd}^{2+}$ and $\mathrm{Pb}^{2+}$ ions sorption capacity of dried pretreated C. elegans.

Sorption conditions: $\mathrm{C}_{\mathrm{i}}=300 \mathrm{mg} / \mathrm{l} ; \mathrm{m}=200 \mathrm{mg} / \mathrm{l} ; \mathrm{T}=25^{\circ} \mathrm{C}$; contact time $=60 \mathrm{~min}$ $\left(\right.$ for $\left.\mathrm{Cd}^{2+}\right)$ and $30 \mathrm{~min}\left(\mathrm{~Pb}^{2+}\right)$ and agitation rate $=120 \mathrm{rpm}$. 
For biosorption of heavy metal, $\mathrm{pH}$ is one of the most important environmental factors. The $\mathrm{pH}$ value of solution strongly influences not only the dissociation site of the biomass surface, but also the solution chemistry of the heavy metals: hydrolysis, complexation by organic and/or inorganic ligands, redox reactions, precipitation, the speciation and the biosorption availability of the heavy metals (Esposito et al., 2002 and Wang, 2002). Teemu et al. (2008) reported that an increase in cadmium and lead removal was observed when the $\mathrm{pH}$ was raised over 3. This indicated that the increased binding may result from deprotonation of carboxyl groups. They also found that, the dependence of $\mathrm{pH}$ indicated that ion exchange was probably at least partly responsible for the observed cadmium and lead binding. At low $\mathrm{pH} 3$, the biosorption capacities for all cadmium and lead are low, because the positively charged hydrogen ions compete with metal ions at sorption sites. As the $\mathrm{pH}$ (form 3 to 5) for cadmium and (From 3 to 6) for lead increases, more negatively charged cell surface becomes available thus facilitating greater metal uptake (Ahuja et al., 1999). On the other hand, too high $\mathrm{pH}$ value can cause precipitation of metal complexes, which may complicated the sorption process, so it should be avoided during experiments (Wang \& Chen, 2006 and Farah et al., 2007).

\section{Effect of temperature}

The effect of temperature on cadmium and lead biosorption is represented in Fig. 3. Over the range $\left(20-40^{\circ} \mathrm{C}\right)$, the temperature- related effects do not appear to be particularly pronounced. Maximum biosorption for cadmium and lead occurred at $25^{\circ} \mathrm{C}$.

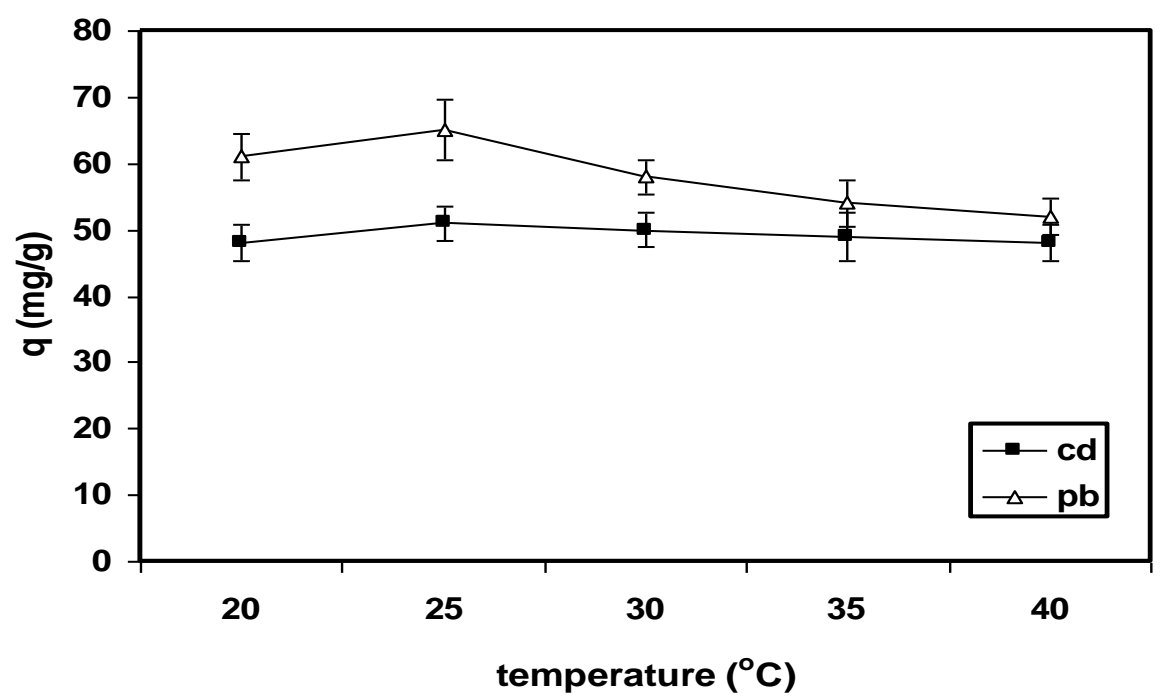

Fig. 3. Effect of temperature on $\mathrm{Cd}^{2+}$ and $\mathrm{Pb}^{2+}$ ions sorption capacity of dried pretreated C. elegans.

Sorption conditions: $\mathrm{C}_{\mathrm{i}}=300 \mathrm{mg} / \mathrm{l} ; \mathrm{m}=200 \mathrm{mg} / \mathrm{l} ; \mathrm{pH}=5.0\left(\right.$ for $\mathrm{Cd}^{2+}$ ) and 6.0 (for $\left.\mathrm{Pb}^{2+}\right)$; contact time $=60 \mathrm{~min}\left(\right.$ for $\left.\mathrm{Cd}^{2+}\right)$ and $30 \mathrm{~min}\left(\mathrm{~Pb}^{2+}\right)$ and agitation rate $=120 \mathrm{rpm}$ 
The decrease in biosorption capacity at higher temperature between 25 and $40^{\circ} \mathrm{C}$ may be due to the damage of active binding sites of the cell surface available for metal biosorption (Ö̈zer \& Özer, 2003). On the other hand, higher temperature usually enhance sorption due to the increased surface activity, binding sites on the relevant cell mass and kinetic energy of the solute (Vijayaraghavan \& Yun, 2007).

\section{Effect of contact time}

The contact time is of great importance in adsorption for the assessment of the suitability of these fungal preparations to serve as biosorbents in a continuous flow system. Fig. 4 shows the effects of contact time for the sorption of $\mathrm{Cd}^{2+}$ and $\mathrm{Pb}^{2+}$ ions by dried pretreated biomass of $C$. elegans. Cadmium and lead uptake increased rapidly with time and reached the maximum after $60 \mathrm{~min}$ and $30 \mathrm{~min}$, respectively. The rapid $\mathrm{Cd}^{2+}$ and $\mathrm{Pb}^{2+}$ uptake proves that the removal of them by C. elegans is due to adsorption or bioadsorption which typically occurs rapidly (Nabil et al., 1997).

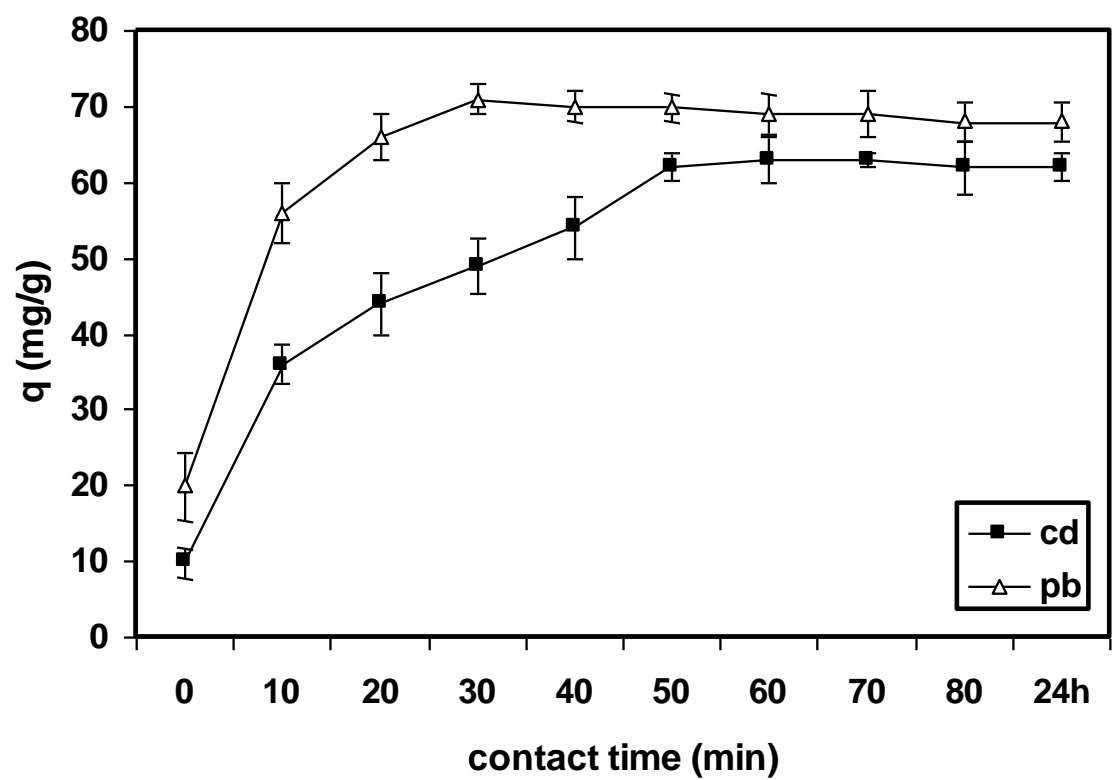

Fig. 4. Effect of contact time on $\mathrm{Cd}^{2+}$ and $\mathrm{Pb}^{2+}$ ions sorption capacity of dried pretreated $C$. elegans.

Sorption conditions: $\mathrm{C}_{\mathrm{i}}=300 \mathrm{mg} / \mathrm{l} ; \mathrm{m}=200 \mathrm{mg} / \mathrm{l} ; \mathrm{pH}=5.0$ (for $\mathrm{Cd}^{2+}$ ) and 6.0 (for $\left.\mathrm{Pb}^{2+}\right) ; \mathrm{T}=25^{\circ} \mathrm{C}$ and agitation rate $=120 \mathrm{rpm}$

Effect of agitation rate

The effect of the turbulence of the sorbent/sorbate system in cadmium and lead adsorption was monitored at low, medium and high speeds of agitation using a nonagitated system as the control $(0-200 \mathrm{rpm})$. All agitation speeds were found to have a positive effect over the non-agitated system as exemplified in Fig.5. Optimal

Egypt. J. Microbiol. 46 (2011) 
values of adsorption capacity are obtained at the stirring speed of $120 \mathrm{rpm}$ for cadmium and lead. This is because agitation at this speed may facilitates proper contact between the metal ions in solution and the biomass binding sites and thereby promotes effective transfer of sorbate ions to the sorbent sites. The moderate speed gives the best homogeneity for the mixture suspension (Bai \& Abraham, 2001). But, high stirring speed, vortex phenomenon occurs and the suspension is no longer homogenous which makes the adsorption of cadmium and lead difficult (Yun-Guo et al., 2006).

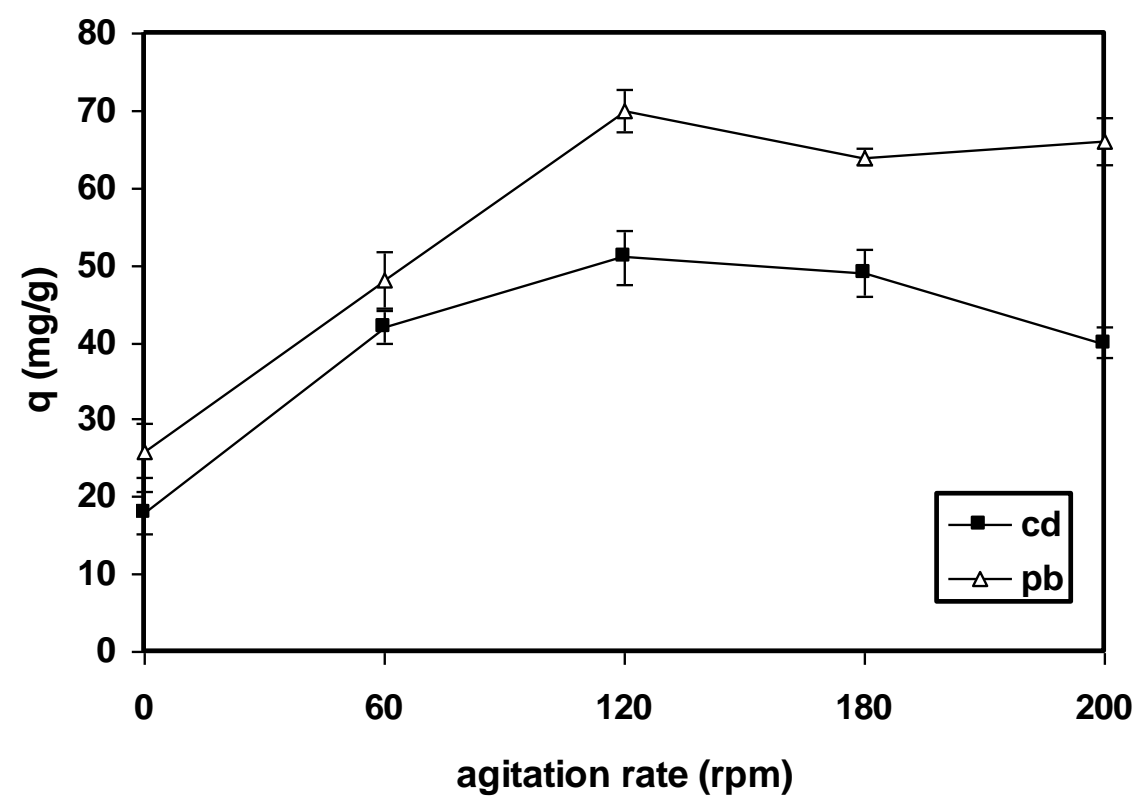

Fig.5. Effect of agitation rate on $\mathrm{Cd}^{2+}$ and $\mathrm{Pb}^{2+}$ ions sorption capacity of dried pretreated C. elegans.

Sorption conditions: $\mathrm{C}_{\mathrm{i}}=300 \mathrm{mg} / \mathrm{l} ; \mathrm{m}=200 \mathrm{mg} / \mathrm{l} ; \mathrm{pH}=5.0$ (for $\mathrm{Cd}^{2+}$ ) and 6.0 (for $\left.\mathrm{Pb}^{2+}\right) ; \mathrm{T}=25^{\circ} \mathrm{C}$ and contact time $=60 \mathrm{~min}\left(\right.$ for $\left.\mathrm{Cd}^{2+}\right)$ and $30 \mathrm{~min}\left(\right.$ for $\mathrm{Pb}^{2+}$ )

\section{Quantification of metal biosorption}

Figures 6-8 represent EDAX spectra and concentrations of semiquantified results of native, cadmium- exposed and lead-exposed cells. The peaks of $\mathrm{Si}$, $\mathrm{P}, \mathrm{S}, \mathrm{Ca}, \mathrm{Ni}$ and $\mathrm{Cu}$ were detected as elements present on the surface of native cells (Fig. 6). The atomic percent of $\mathrm{P}$ and $\mathrm{S}$ increased with $\mathrm{Cd}^{2+}$ and $\mathrm{Pb}^{2+}$ uptake, respectively (Fig. 7 and 8). This coprecipitation of $\mathrm{Cd}^{2+}$ with $\mathrm{P}$ and $\mathrm{Pb}^{2+}$ with $\mathrm{S}$ suggest that phosphate may be sequestering $\mathrm{Cd}$ in the form of $\mathrm{Cd}$ phosphate complexes and $\mathrm{Pb}$ in the form of $\mathrm{Pb}$-sulphate complexes. Aloysius et al. (1999) reported that the mechanism of sequestration of cadmium ions on the surface of Rhizopus oligosporus was proved to be a bioadsorption phenomenon. They also found that the conspicuous phosphorus peak in the EDAX spectrum indicated that the metal may be deposited in the form of

Egypt. J. Microbiol. 46 (2011) 
cadmium phosphate. Ariff et al. (1999) studied the mechanism of lead biosorption by powderized $R$. oligosporus using transmission electron microscope and energy dispersive $\mathrm{X}$-ray analysis. They confirmed that during sorption most of the lead was adsorbed on the surface of cell.

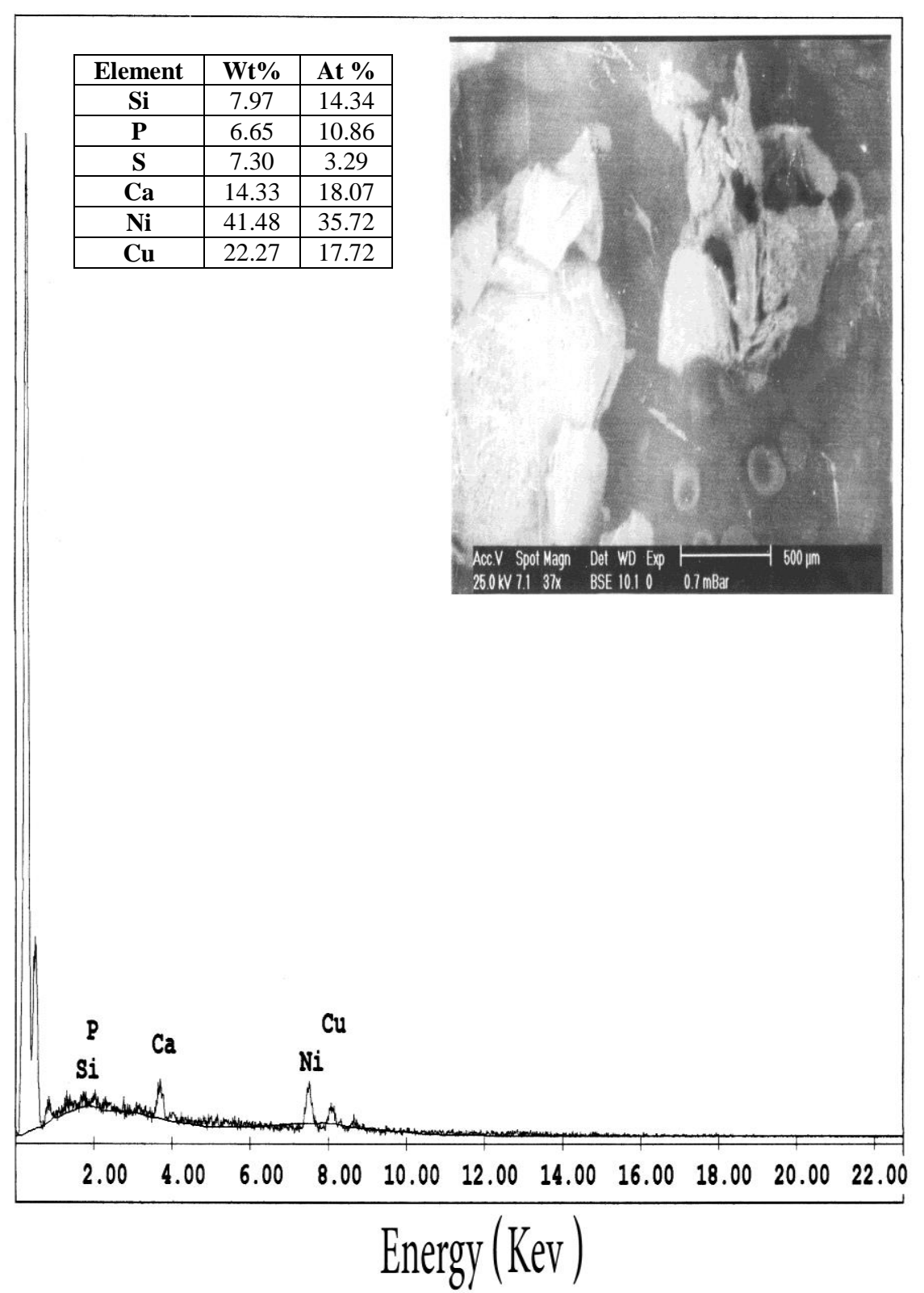

Fig.6. EDAX spectroscopy depicting the presence of elements on native dried biomass of C. elegans. 


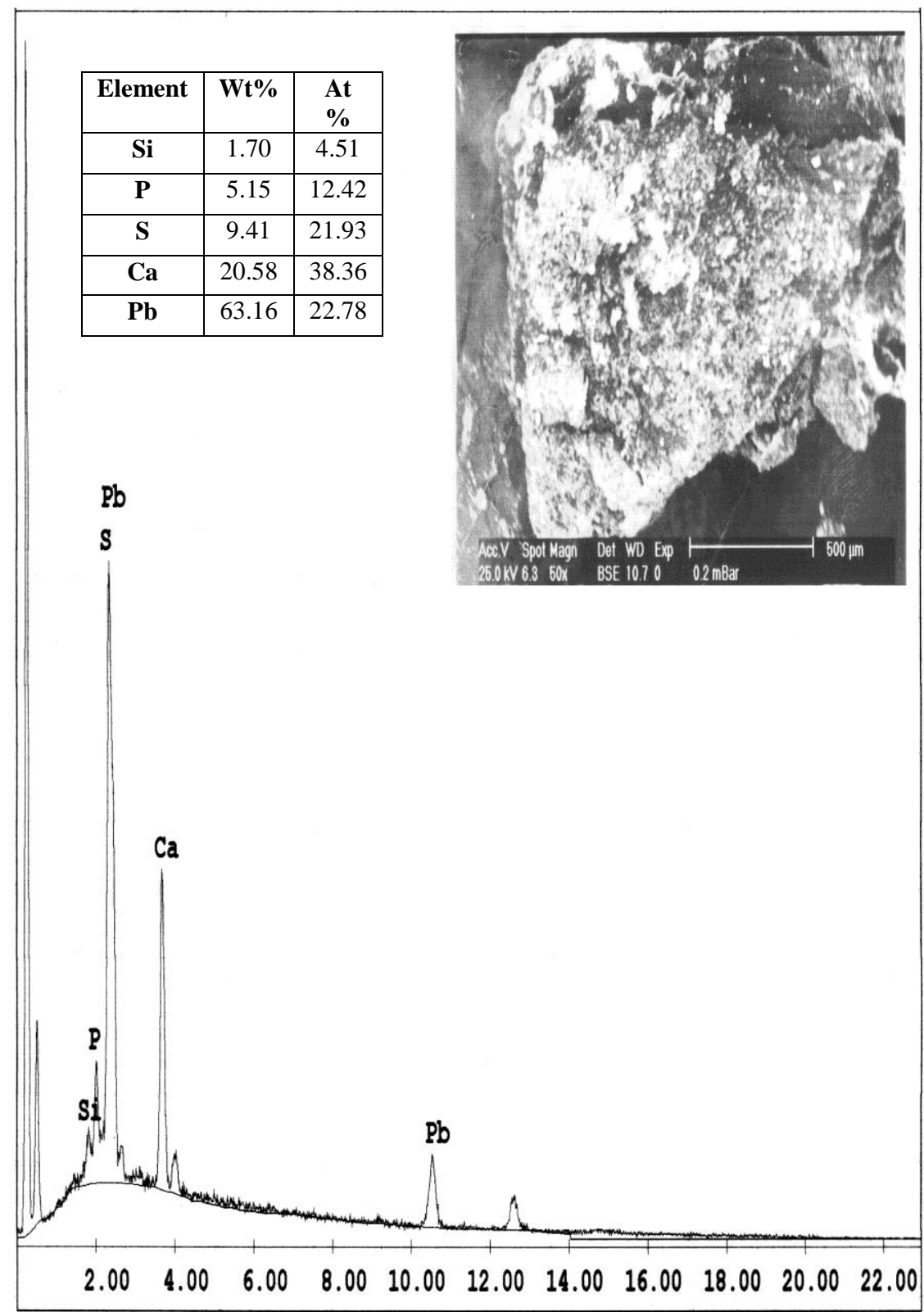

Fig. 7. EDAX spectroscopy depicting the lead biosorption on the tested dried biomass of C. elegans . 


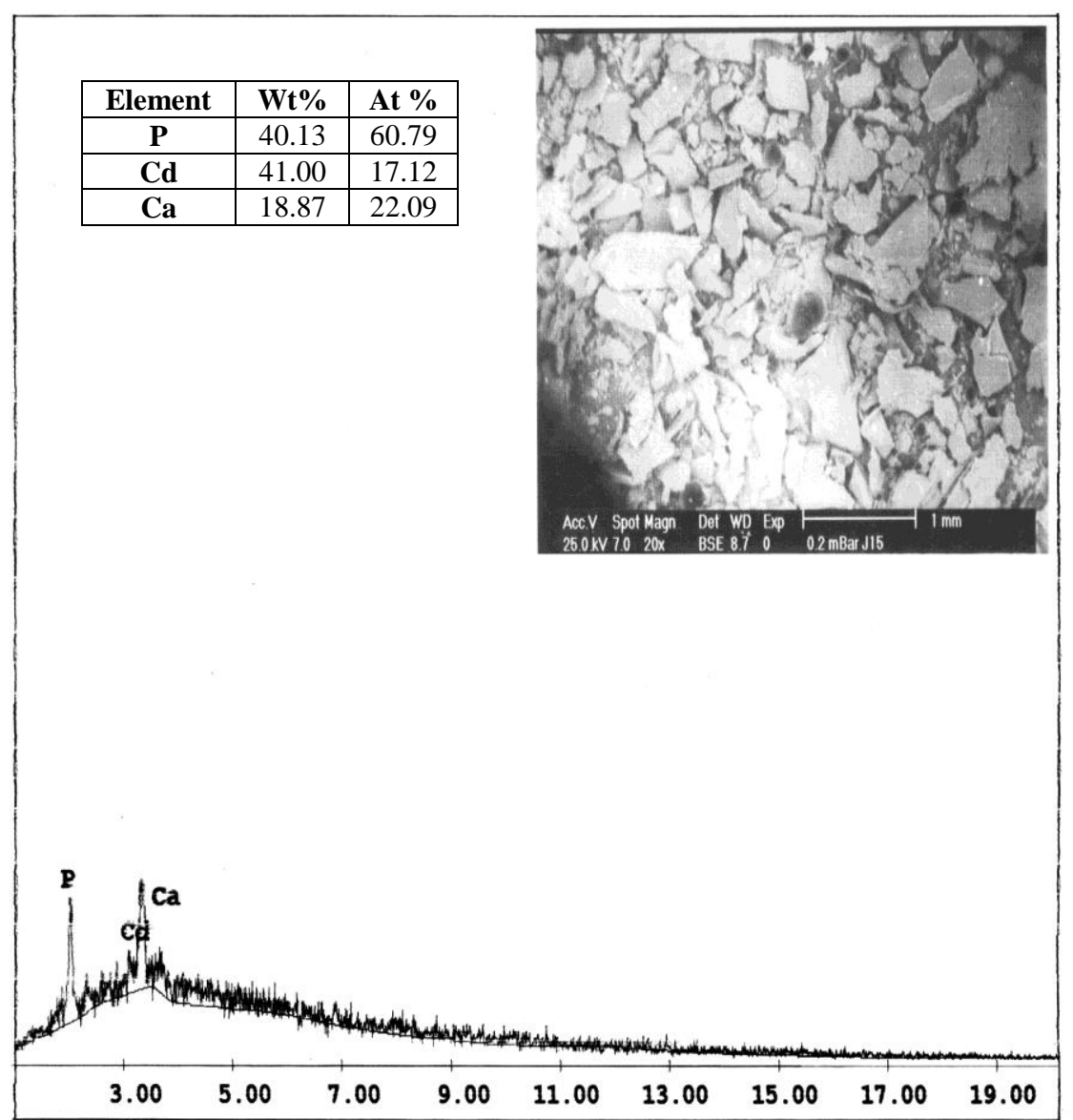

Fig. 8. EDAX spectroscopy depicting the cadmium biosorption on the tested dried biomass of C. elegans .

El-Sayed (2009) using the EDAX analysis indicated higher accumulation of cadmium on Pseudomonas aeruginosa surface more than zinc and copper.

Elution of metal ions biosorbed by dried pretreated biomass and regeneration

The pretreated biomass showed stronger affinity for removal of $\mathrm{Cd}^{+2}$ and $\mathrm{Pb}^{+2}$ from wastewaters of dyes factory and battery factory more than that of chemicals factory. C. elegans Lender biomass was more efficient in the removal of lead especially from battery factory and dyes factory than cadmium from all tested wastewaters. The adsorption is easy to understand when it refers to a single metal situation; however in a multi-ion situation, which is generally encountered in effluent, the assessment becomes complicated. The biosorbed metal ions were eluted from pretreated biomass using three elutants. Table 2 compares the 
removal efficiency of various chemicals in eluting biosorbed metal ions. Deionized water was able to elute biosorbed metal ions only to a limited extent, indicating the strong affinity that biomass possesses towards the metal ions. $15 \mathrm{mM} \mathrm{HNO}$, solution was able to effectively elute the biosorbed cadmium from all used polluted samples. Meanwhile, $10 \mathrm{mM}$ EDTA solution was able to effectively elute the biosorbed lead from all used polluted wastewaters.

TABLE 2. The elution of biosorbed metals from wastewater of chemicals factory, dyes factory and battery factory by various chemical reagents .

\begin{tabular}{|l|c|c|c|c|c|c|}
\hline \multirow{2}{*}{ Chemical } & \multicolumn{2}{|c|}{ Chemicals factory } & \multicolumn{2}{c|}{ Dyes factory } & \multicolumn{2}{c|}{ Battery factory } \\
\cline { 2 - 7 } & $\begin{array}{c}\text { \% recovery } \\
\text { of } \\
\text { biosorbed } \\
\text { Cd }\end{array}$ & $\begin{array}{c}\text { \% recovery } \\
\text { of } \\
\text { biosorbed } \\
\text { Pb }\end{array}$ & $\begin{array}{c}\text { \% recovery } \\
\text { of } \\
\text { biosorbed } \\
\text { Cd }\end{array}$ & $\begin{array}{c}\text { \% recovery } \\
\text { of } \\
\text { biosorbed } \\
\text { Pb }\end{array}$ & $\begin{array}{c}\text { \% recovery } \\
\text { of } \\
\text { biosorbed } \\
\text { Cd }\end{array}$ & $\begin{array}{c}\text { \% recovery } \\
\text { of } \\
\text { biosorbed } \\
\text { Pb }\end{array}$ \\
\hline $\begin{array}{l}\text { Deionized } \\
\text { water }\end{array}$ & 19 & 12 & 15 & 7 & 28 & 11 \\
\hline $\begin{array}{l}10 \mathrm{~m} \mathrm{M} \\
\mathrm{EDTA}\end{array}$ & 35 & 68 & 38 & 98 & 46 & 60 \\
\hline $\begin{array}{l}15 \mathrm{~m} \mathrm{M} \\
\mathrm{HNO}_{3}\end{array}$ & 88 & 48 & 55 & 70 & 61 & 48 \\
\hline
\end{tabular}

The biomass was reused to study the changes in metal biosporption with subsequent usage (Fig. 9). Biomass lost a little portion of its cadmium and lead biosorption capacity for the chemicals factory, on contrary, biomass retain its biosorption capacity for both metal ions from wastewater of dyes factory and battery factory.

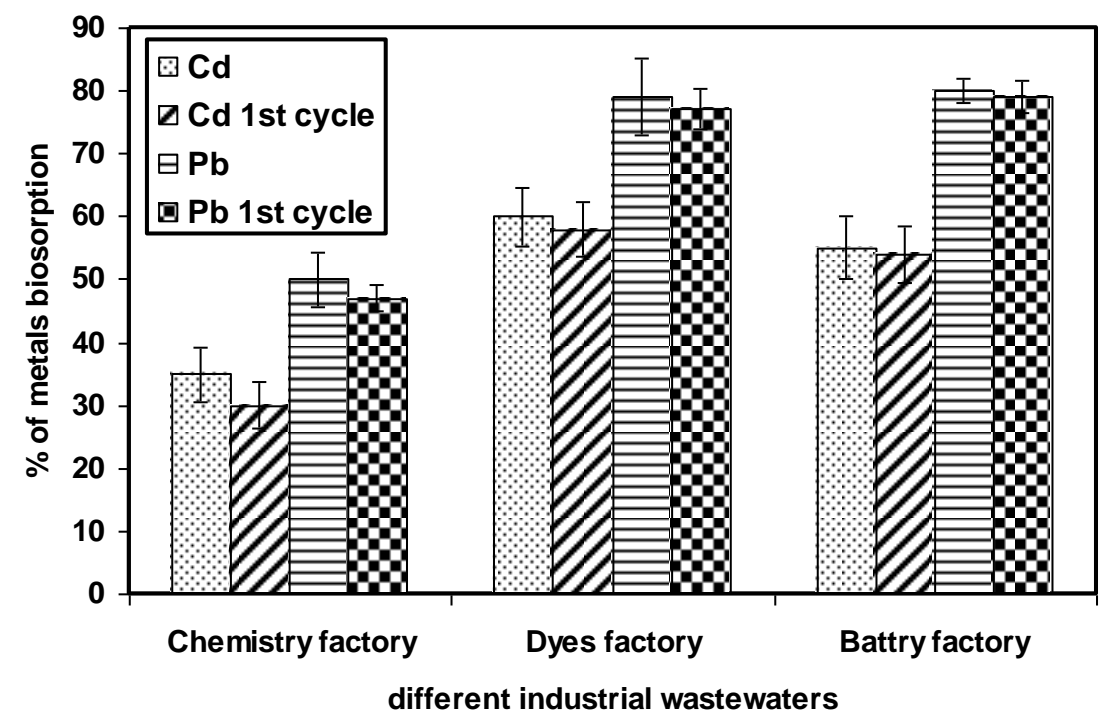

Fig. 9. Sorption of $\mathrm{Cd}^{2+}$ and $\mathrm{Pb}^{2+}$ ions from different wastewaters by dried pretreated C. elegans

Egypt. J. Microbiol. 46 (2011) 
Desorption of loaded biomass enables reuse of the biomass and recovery and/or containment of sorbed materials, it is desirable that the desorbing agents does not significantly damage or degrade the biomass (Gadd, 2008). Yan \& Viraraghavan (2003) reported that metal ions adsorbed by the dead biomass of Mucor rouxii could be eluted effectively with $\mathrm{HNO}_{3}$, while distilled water demonstrated negligible metal elution capability. The degree of reduction in removal depended on the biomass and desorbent used. A variation was reported from $1 \%$ to $63 \%$ for dilute acid, and from $6.5 \%$ to $30 \%$ for EDTA (Senthilkumar et al., 2007). This was in agreement with the explanation by Teemu et al. (2008) who mentioned that the reduction in metal removal may also be related to concomitant removal of some surface components by acids and EDTA.

Acknowledgement : The authors are most indebted to Professor of Mycology, Gamal El-Deen Helal for identify fungal isolates, his great help and guidance during this research.

\section{References}

Ahluwalia, S.S. and Goyal, D. (2007) Microbial and plant derived biomass for removal of heavy metals from wastewater. Bioresource Technology, 98, 2243 - 2257.

Ahmed, I., Zafar, S. and Ahmed, F. (2005) Heavy metal biosorption potential of Aspergillus and Rhizopus sp. isolated from wastewater treated soil. Journal Applied Sciences \& Environmental Management, 9, 123 - 126.

Ahuja, P., Gupta, R. and Saxena, R.K. (1999) $\mathrm{Zn}^{2+}$ biosorption by Oscillatoria anguistissima. Process Biochemistry, 34, 77 - 85.

Amini, M., Younesi, H., Bahramifar, N., Lorestani, A.A., Ghorbani, F., Daneshi, A. and Sharifzadeh, M. (2008) Application of response surface methodology for optimization of lead biosorption in an aqueous solution by Aspergillus niger. Journal of Hazardous Materials, 154, 694 - 702.

Ariff, A.B., Mel, M., Hasan, M.A. and Karim, M.I. (1999) The kinetics and mechanism of lead (II) biosorption by powderized Rhizopuss oligosporus. World Journal of Microbiology and Biotechnology, 15, 291 - 298.

Bai, S. and Abraham, T.E. (2001) Biosorption of $\mathrm{Cr}$ (VI) from aqueous solution by Rhizopas nigricans. Bioresource Technology, 79, 73 - 81.

Bayramoglu, G., Celik, G., Yalcin, E., Yilmaz, M. and Arica, M.Y. (2005) Modification of surface properties of lentinus sajor-caju mycelia by physical and chemical methods: Evaluation of their $\mathrm{Cr}$ (VI) removal efficiencies from aqueous medium. Journal of Hazardous Materials, 119, 219 - 229.

Chen, Y. and Lian, B. (2005) Ability of Bacillus mucilaginosus GY03 strain to adsorb chromium ions. Pedosphere, 15, 225-231.

Domsch, K.H., Gams, W. and Anderson, T.H. (1980) “Compendium of Soil Fungi". London, U.K., Academic Press. 
El-Morsy, E.M. (2004) Cunninghamella echinulata a new biosorbent of metal ions from polluted water in Egypt. Mycologia, 96, 1183 - 1189.

El-Sayed, S.M. (2009) Effect of certain heavy metals stress on metabolic activities of some bacterial strains. Ph.D. Thesis, Botany Department, Faculty of Science, Zagazig University, Zagazig, Egypt.

Errasquin, E.L. and Vázquez, C. (2003) Tolerance and uptake of heavy metals by Trichoderma atroviride isolated from sludge. Chemosphere, 50, 137 - 143.

Esposito, A., Pagnanelli, F. and Veglio, F. (2002) pH-related equilibria models for biosorption in single metal systems. Chemical Engineering Science, 57, 307-13.

Farah, J.Y., El-Gendy, N.Sh. and Farahat, L.A. (2007) Biosorption of Astrazone Blue basic dye from an aqueous solution using dried biomass of Baker's Yeast. Journal of Hazardous Materials, 148, $402-408$.

Gadd, G.M. (2007) Fungi and industrial pollutants. In: "Environmental and Microbial Relationships", $2^{\text {nd }}$ ed. pp. $69-84$.

Gadd, G.M. (2008) Biosorption: critical review of scientific rationale, environmental importance and significance for pollution treatment. Journal of Chemical Technology and Biotechnology, 84, $1-23$.

Gams, W., Hoekstra, E.S. and Aptroot, A. (1998) CBS course of Mycology Ponsen and Looyen BV, Wageningen, the Netherland.

Gavrilescu, M. (2004) Removal of heavy metals from the environment by biosorption. Engineering in Life Sciences, 4, 219 - 32.

Göksungur, Y., Üren, S. and Güvenc, U. (2005) Biosorption of cadmium and lead ions by ethanol treated waste Baker's Yeast biomass. Bioresource Technology, 96, 103 109.

Gulnaz, O., Saygideger, S. and Kusvuran, E. (2005) Study of $\mathrm{Cu}$ (II) biosorption by dried activated sludge: effect of physico-chemical environment and kinetics study. Journal of Hazardous Materials, B120, 193 - 200.

Hayat, S., Ahmed, I., Azam, Z.M., Ahmed, A., Inam, A. and Samiullah (2002) Effect of longterm application of oil refinery wastewater on soil health with special reference to microbiological characteristics. Bioresource Technology, 84, 159-163.

Ibrahim, I.H., Abd El-Wahed, A.A. and Ali, M.A. (2004) Mineralgical and spectrometric studies of El-SIBAI Shear zone, Central Eastern Desert, Egypt. $6^{\text {th }}$ International Conference on Geochemistry, Alexandria University, Egypt. pp.25 - 43.

Incharoensakdi, A. and Kitjaharn, P. (2002) Zinc biosorption from aqueous solution by a halotolerant cyanobacterium, Aphanothece halophytica. Current Microbiology, 45, $261-264$.

Järup, L. (2003) Hazards of heavy metal contamination. British Medical Bulletin, 68, $167-182$

Egypt. J. Microbiol. 46 (2011) 
Javaid, A. and Bajwa, R., (2008) Biosorption of electroplating heavy metals by some basidiomycetes. Mycopath, 6, $1-6$.

Kapoor, A. and Viraraghavan, T. (1995) Fungal biosorption an alternative treatment option for heavy metal bearing wastewaters: a review. Bioresource Technology, 53, $195-206$

Kapoor, A., Viraraghavan, T. and Cullimore, D.R. (1999) Removal of heavy metals using the fungus Aspergillus niger. Bioresource Technology, 70, 95 - 104.

Korboule, N., Sylvie, D. and Gilles, B. (2002) Environmental risk of applying sewage sludge compost to vineyard: Carbon, heavy metals, nitrogen and phosphorus accumulation. Journal of Environmental Quality, 31, 15 - 1527.

Krim, L., Nacer, S. and Bilango, G. (2006) Kinetics of chromium sorption on biomass fungi from aqueous solution. American Journal of Environmental Sciences, 2, 27-32.

Malik, A. and Jaiswal, R. (2000) Metal resistance in Pseudomonas strains isolated from soil treated with industrial wastewater. World Journal of Microbiology and Biotechnology, 16, 177 - 182.

Moubasher, A.H. (1993) "Soil Fungi in Qatar and Other Arab Countries". Center for Scientific and Applied Research, Qatar University.

Nabil, H., Abdel-Razek, A.S. and Hafez, M.B. (1997) Accumulation of heavy metals on Aspergillus flavus. Journal of Chemical Technology and Biotechnology, 68, $19-22$.

Özer, A. and Özer, D. (2003) Comparative study of the biosorption of $\mathrm{Pb}$ (II), Ni (II) and $\mathrm{Cr}$ (VI) ions onto $S$. cerevisiae: Determination of biosorption heats. Journal Hazardous Materials, B 100, 219 -229.

Selatnia, A., Bakhti, M.Z., Madani, A., Kertous, L. and Mansouri, Y. (2004a) Biosorption of $\mathrm{Cd}^{2+}$ form aqueous solution by a $\mathrm{NaOH}^{-}$treated bacterial dead Streptomyces rimosus biomass. Hydromettallurgy, 75, 11 - 24.

Selatnia, A., Boukazoula, A., Kechid, B.N., Bakhti, M.L., Chergui, A. and Kerchich, Y. (2004b) Biosorption of lead (II) from aqueous solution by a bacterial dead Streptomyces rimosus biomass. Biochemical Engineering Journal, 19, 127 - 135.

Senthilkumar, R.; Vijayaraghavan, K., Thilakavathi, M., Lyer, P.V.R. and Velan, M., (2007) Application of seaweeds for the removal of lead from aqueous solution. Biochemical Engineering Journal, 33, 211- 216.

Sheng, P.X., Ting, Y., Chen, J.P. and Hong, L. (2004) Sorption of lead, copper, cadmium, zinc and nickel by marine algal biomass: characterization of biosorptive capacity and investigation of mechanisms. Journal of Colloid Interface Science, 275, 131- 141.

Teemu, H., Seppo, S., Jussi, M., Raija, T. and Kalle, L. (2008) Reversible surface binding of cadmium and lead by lactic acid and bifidobacteria. International Journal of Food Microbiology, 125, 170 - 175.

Tobin, J., White, C. and Gadd, G.M. (1994) Metal accumulation by fungi: Applications in environmental biotechnology. Journal of Industrial Microbiology, 13, 126 - 130.

Egypt. J. Microbiol. 46 (2011) 
Tsekova, K. and Petrov, G. (2002) Removal of heavy metals from aqueous solution using Rhizopus delemar mycelia in free and polyurethane-bound form. Zeitschrift für Natureforschung, 57, 629-633.

Vanloon, J.C. and Lichwa, J. (1973) A study of atomic absorption determination of some important heavy metals in fertilizers and domestic sewage plant sludges. Environmental Letters. 4, $1-8$.

Vasudevan, P., Padmavathy, V. and Dhingra, S.C. (2003) Kinetics of biosorption of cadmium on baker's yeast. Bioresource Technology, 89, 281- 287.

Vijayaraghavan, K. and Yun, Y. (2007) Utilization of fermentation waste (Corynebacterium glutamicum) for biosorption of Reactive Black 5 from aqueous solution. Journal of Hazardous Materials, 141, 45 - 52.

Vijayaraghavan, K. and Yun, Y. (2008) Bacterial biosorbents and biosorption. Biotechnology Advances, 26, 266 - 291.

Volesky, B. (2007) Biosorption and me. Water Research, 41, 4017 - 4029.

Volesky, B. and Holan, Z.R. (1995) Biosorption of heavy metals: a review. Biotechnology Progress, 11, 235 - 250.

Wang, J. (2002) "Microbial Immobilization Techniques and Water Pollution Control". Bijing, Science Press. pp. 233 - 248.

Wang, J. and Chen, C. (2006) Biosorption of heavy metals by Saccharomyces cerevisiae: a review. Biotechnology Advances, 24, 427-451.

Yan, G. and Viraraghavan, T. (2003) Heavy metal removal from aqueous solution by fungus Mucor rouxii. Water Research, 37, 4486 - 4496.

Yun-Guo, L., Ting, F. and Guang-ming, Z. (2006) Removal of cadmium and zinc ions from aqueous solution by living Aspergillus niger. Transactions of Nonferrous Metals Society of China, 16, $681-686$.

Zafar, S., Aqil, F. and Ahmed, I., (2007) Metal tolerance and biosorption potential of filamentous fungi isolated from metal contaminated agricultural soil. Bioresource Technology, 98, $2557-2561$

(Received 24/2/2011;

accepted 5/10/2011) 


\title{
الأمتصاص الحيوى لأيونات الكادميوم والرصاص بواسطة الكتلة
} الحيوية لـ Cunninghamella elagans

\author{
منال توفيق السيد إبراهيم وفيفى محمد رضا

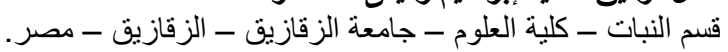

\begin{abstract}
تم عزل فطرة Cunninghamella elagans من نربة زراعية معالجة بمياه

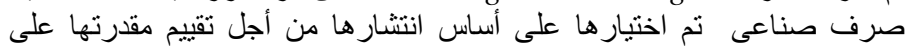

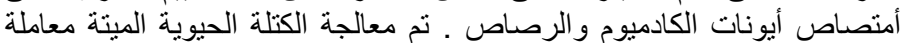

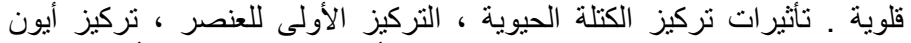

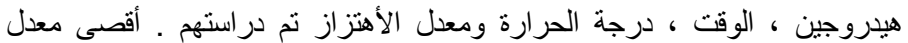

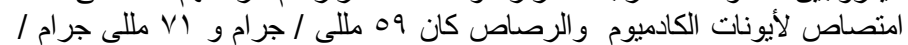

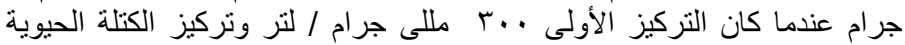

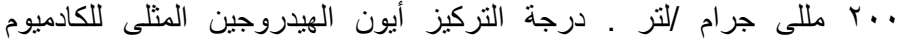

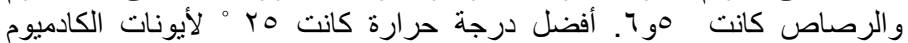

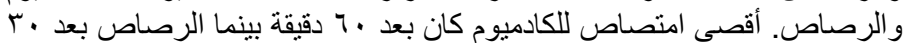

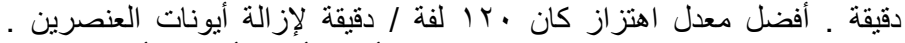

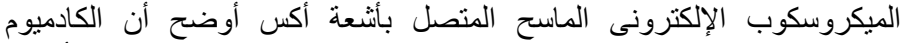

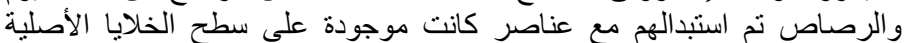

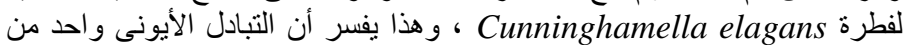

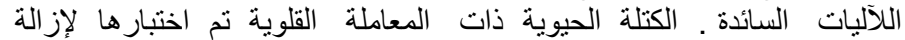

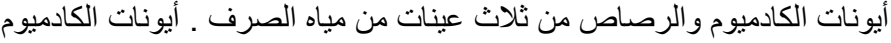

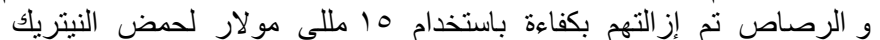

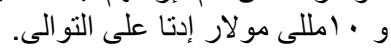

